\title{
The Geo-biographies of Spatial Knowledge: Regional Planning from Israel to Sierra Leone and Back
}

\section{Introduction}

Like all other disciplines in the modern university, Geography has a geography. And, like most other formations in late modernity, disciplinary Geography is implicated in globalization (Jazeel, 2016: 649)

This quote opens an article by Tariq Jazeel, in which he argues that the circulation of knowledge production in various disciplines is not only geographical, but that one should consider the ways in which knowledge production is transplanted in concrete settings and rearticulates itself. Jazeel's call for the return of researchers' involvement in area studies, particularly in the global south, provides a framework for this article, which seeks to reflect not only upon the geography of spatial and planning knowledge but also upon its biography. In other words, we aim to show how spatial knowledge has a "geo-biography", which illustrates the ways in which the personal embodied biographies of human agents might allow us to better understand the geography of knowledge circulation. We focus on planning knowledge, which is an important segment of spatial knowledge. Planning knowledge is not merely the generator of discourse and of the professional community partaking in it, but also traverses space, crossing national borders and geographies (Perera, 2008) as both theory and applicative practice (Healey, 2010). This dynamic has a politics of its own, as part of its movement and development within the global space, particularly in the movement between first 
and third worlds (Roy, 2010; Perera, 2008). It encompasses rich personal stories embedded in the lives and biographies of the planners who are the vehicles of its creation (Friedmann, 2010a).

Thoroughout this article we claim that there is a great relevance to current trends in geography, urban studies and planning theory that focus on cities of the Global South-East, where issues differ significantly from the northern contexts (Watson, 2009, 2012; Yiftachel, 2006). As shown recently by Schmidt and Purwins (2017), many contemporary challenges faced by societies in the Global South continue to be similar to challenges faced several decades ago by Western societies.

Although the current South-East discourse focuses on the ways in which scholars view the geography of knowledge production, our study aims to contribute to this discussion by exploring a different case, in which spatial knowledge flowed indirectly from the West to the third world on one hand, but also developed simultaneously in Israel and in de-colonised Africa, on the other. This study contributes to the current discussion about the circulations of spatial knowledge, that is usually perceived as uni-directional, from the West to the Global South-East (Watson, 2009, 2012; Yiftachel, 2006), or in the Israeli context, from Europe to Israel (Shevah and Kallus, 2016; Sharon, 2016), and from Israel to Africa (Oded, 2011; Yacobi, 2016). Furthermore, we also aim to contribute to the historically connected arts of geography and biography (Daniels and Nash, 2004), highlighting the importance of biography and personal life stories and their contributions to the understanding of geographical and spatial knowledge (McGeachan et al, 2012).

The main question articulated throughout this article is what is the geobiography of spatial knowledge in time and space? In order to answer this, we will examine the geographies of spatial knowledge and its transplantation in different geographical scales in the work of two Israeli planners - Arie Dudai and Ursula 
Oelsner. More specifically, we examine the ways in which Dudai and Oelsner adopted principles of knowledge that oscillated during the 1960's between Europe, Israel and Africa, and assimilated them in their work. This knowledge and the resulting planning paradigm are known as "regional planning".

Regional planning knowledge has its own geography. It began as a theoreticalprofessional body of knowledge in Europe, primarily in Britain and Germany. In the US it developed between the two world wars, spreading to other European countries such as the Netherlands and Greece after the second world war ${ }^{1}$. Regional planning knowledge arrived to Israel during the 1950's and was advanced by local planners such as Eliezer Brutzkus and Arthur Glikson, who developed different theoretical approaches to the concept. Their writings had gained international acclaim, widespread publication and historiographical attention, whereas other planners who assimilated their ideas, developed them and attempted to examine them in the planning practice in Israel (and as we show later, in Africa as well), were to a large extent sidelined and forgotten. The cases examine here are not intended to describe the Israeli planning of the time, nor to serve as a model for planning in Africa, but rather to examine the special characteristics of knowledge production and circulation made by these two planners.

A secondary objective of this article, therefore, is to illuminate the work of two planners who participated in the local and international arena of planning and development, and to draw attention to their work. They were important for professional and political reasons - both were deeply involved in the creation of Israel's "new geography" (Dudai was also part of the team who planned the first Israeli master plan, headed by Arie Sharon), but both also contributed to the politics of the field and profession of spatial planning in Israel, as we will show later (e.g. their contribution to

\footnotetext{
${ }^{1}$ It is important to note that due to different planning cultures (and knowledge!), there are many regional planning approaches in Europe and the US, which are beyond the discussion in this paper.
} 
the Israeli Association of Planners). We will draw attention to their work by presenting and discussing two projects they jointly planned during the 1960's - the initial, pioneering plans of the city of Macabit (known by its contemporary name - Modi'in), and national plans for the urbanization of Sierra Leone.

While Dudai was a prominent planner in Israel and one of the "fathers" of the discipline in the country (Efrat, 1997), his work in western Sierra Leone was only recently researched (Levin, 2015). The case of Oelsner is even less known, since despite her voluminous work in planning over the course of several decades, she was never considered to be as prominent as Dudai, and in part of their joint projects, including those discussed in this article, her contribution is altogether absent from the historical record.

This phenomenon is common within the field of planning, which was established as a masculine endeavor in the western world (Leavitt, 1980; Olufemi, 2008; Sandercock and Forsyth, 1992;). Despite changes in the last decades with the increasing female presence in the field, Oelsner's work has not yet been revealed nor discussed. Particularly significant to the perspective of this article is the fact that Oelsner worked not only within the Israeli planning field, but also in Greece, Singapore and Africa. As the pioneering studies of female planners and architects who worked in Africa demonstrate (Lee, 2008), the number of women who worked in this field in Africa during the twentieth century was small and their contributions are virtually unknown.

The first section of the article includes a brief overview of the geographies of regional planning knowledge. Afterwards, we will present the biographies of Dudai and Oelsner, and discuss the two cases through which we will attempt to examine the migration of regional planning knowledge and its translation into planning praxis in Israel and Africa. 


\section{Spatial Knowledge and the Geographies of Regional Planning}

\section{Spatial knowledge, production and circulation}

Planning theorists have raised the question whether knowledge of planning is only deductive, in as much as it contains principles true to any place and time, or is it also inductive, as in something that could it be achieved by generalizations drawn from former experience? (Fenster and Kulka, 2016; Fenster and Misgav, 2014; Rydin, 2007; Sandercock, 1998). Knowledge of planning is created by the discourse among planners (who create it), between them and the users, and among communities of people creating it in practice and sharing it, called in professional literature "communities of practice" (Yacobi, 2009). It is also essential to understand that planning, as a theory and even more as a practice that aims to "change the world", operates at the interface of knowledge and action, e.g., as an activity concerned with intervening and taking action to realize better place-based outcomes (Campbell, 2012).

Recently, some scholars have identified the differences between professional and local knowledge in planning (Fenster and Kulka, 2016; Fenster and Misgav, 2014; Rydin, 2007; Sandercock, 1998). Professional knowledge, e.g. the knowledge carried by architects, geographers and planners, is connected to the rise of the modern state and rational (e.g., professional, mainly quantitative and "scientific") planning (Holston, 1989; Ward, 2002). Local knowledge is perceived as more personal and intimate, and is connected to real-life situations and the intimate knowing of the environment by people, based on their daily use of spaces (Fenster and Kulka, 2016; Sandercock, 1998). Fenster and Kulka (2016) have referred to this knowledge as lay knowledge, that is, the knowledge that every person possesses as a result of embodied and sensual use of the environment. They emphasize how nuanced relations between various types of 
knowledge better explain the challenges faced by planners and residents, thus challenging the binary view of professional/powerful versus local/powerless knowledge that characterizes modernist thinking.

This paper investigates a pervious era, when modernist planning and professional knowledge were more dominant. We then show how embodied spatial knowledge moves from one place to another and what happens if it lands in a different context and situation. We refer mainly to professional knowledge, as conceptualized by later scholars (Fenster and Kulka, 2016; Rydin, 2007; Sandercock, 1998), but at the same time we also examine embodied and personal knowledge, e.g. knowledge based on personal experience, biographies and different backgrounds of planners. By doing so we add another layer of (a later) understanding of the binary view of the difference between professional and locallay knowledge, and how they characterized modernist thinking.

\section{Geo-Biographies: The role of personal biographies and place-based planning}

Some scholars (Longhurst, 2009) have challenged the idea that spatial knowledge is simply "out there", waiting to be discovered. Spatial knowledge, then, is both "embodied" and "situated", that is, made by individuals who are situated within particular contexts, biographies and places (ibid). Life stories and personal biographies of architects and planners have received public attention and popular writing mainly when it came to key figures such as Le-Corbusier, Ebenezer Haward, Lewis Mumford, Patrick Geddes and others that have changed the profession. Unlike the field of historical geography where a variety of forms of life writing are in use, such as autobiographies, travel writings, novels, educational texts or memoirs of professional geographers (Daniels and Nash, 2004), very little has been written regarding the life stories and biographies of non-famous practitioners and planners in order to learn from 
their biographies about their use of professional and personal knowledge, its development and circulation.

In the Israeli context, some leading planners have received scholarly attention within the spatial disciplines, but their personal life stories and geo-biographies were not in the focus of research (Kallus, 2015; Sharon, 2006; Wilkof, 2018). A project edited by Forester et-al (2001) was unique in its focus on Israeli planners by telling their personal stories, and analyzing their professional outcomes by understanding their "knowledge, skills, savvy, sensitivity and courage" (ibid, 1). While their aim was to reflect on and present a wide range of Israeli planners that demonstrate (as claimed by the editors) the "Multicultural Israeli Society" (ibid, 2), we focus on two planners by studying both their personal biographies and professional outcomes.

Since our aim is to understand the geo-biographies of these two planners and how their knowledge traveled and was circulated, it is essential also to understand that spatial knowledge and experience cannot be "copied and pasted" from one place to another. Rather, it needs to be transferred carefully and adapted in order for it to land in a different culture, and this paper examines knowledge from Europe, which is transferred to Israel or Africa.

This understanding highlights the importance of place and place-based planning, together with the personal biographies of the planners - we conceptualize this as the “Geo-Biographies of spatial knowledge”. As argued by Beauregard (2016), little has been written about the ways in which places enter into planning practice. Attention is mainly directed at places that have already been or are being planned, and the planning decisions, and less on the ways in which spatial knowledge is connected to the geobiographies of the people who produce it. Planning, thus, is a "spatial strategy" (Healey, 2006) that has to do with the different planning cultures and places (Beauregrad, 2016; 
Friedmann, 2010b; Healey, 2004; Graham and Healey, 1999).

\section{Regional Planning as a Concept}

Regional planning is a practical expression of regionalism - a practice that makes use of regions and regional thinking in order to attain specific objectives in the context of development and planning. The history of regional planning as an institutional practice spans less than a hundred year, and despite its roots in approaches and theories of planning that were developed in the second half of the nineteenth century, its operative and significant development began between the two World Wars (Soja, 2000; 2009).

The regional thinking that grew in Europe and in North America is based on the geographical concept of "region". Regional planning grew hand in hand with the emergence of the discipline of regional geography, and from the industrialization and development of the end of the nineteenth century (Soja, 2000). John Friedmann (1964) points out that regional planning is often implicated in questions of metropolitan development, resource management, and agriculture and community improvement. Importantly, he claims that the idea of regional planning as a paradigm is better suited to developing nations or nations undergoing development processes than to fullydeveloped industrialized economies. He locates the emergence of the discipline in planning schools in the post-World War II period, when the predominant aspiration was to use these ideas in planning marginal, less developed regions within highlyindustrialized developed countries.

Regional planning became much more predominant after World War II, as a result of pressing needs of development and rebuilding, especially in Europe. Exchange 
and dissemination of professional and theoretical knowledge on the subject began then, initially consigned primarily to Europe and the United States but later meandered onwards to Third World countries, and during the Cold War to states within the Communist orbit as well (Hecht, 2011; McEwan, 2009). Similarly, Israel sought to export Israeli experience in regional planning - national or local - to developing nations such as Sierra Leone.

\section{Regional planning in Palestine/Eretz Israel ${ }^{2}$}

Ideas connected to regional planning reached Palestine/Eretz Israel in the 1930 's, and were developed mainly by institutes dealing with planning and settlements. These institutes operated side by side with the planning institutions of the British Mandate government. Zionism regarded planning as a primary form of civic activism, whose objectives were to attain (Jewish) national goals, while reinforcing the future state, and later the strategic security requirements of the newly established state.

Israeli planners, educated in Europe, brought with them the European geographic models of "organic" growth and chain of hierarchy between settlements dependant on each other, especially affected by the work of German geographer Walter Christaller, ${ }^{3}$ and by the ideas and approaches of the Garden City Movement and of regional planning formulated by Patrick Geddes (Hysler Rubin, 2011).

The Israeli Governmental Planning Department, which inherited most of the functions of the Mandatory Planning Division, was founded in July 1948 and became

\footnotetext{
2"Palestine/Eretz Israel" is the official connotation employed by the British Empire's Mandate (1919-1948), to describe the mandatory territory of Palestine. 'Eretz Israel' is Hebrew for 'The land of Israel'.

${ }^{3}$ On the work of Christaller, which was taught for a long time in Israel in the Technion and geography departments throughout the country see Golan, 1997. On the ways in which the Nazi regime adopted his ideas of regional development and planning and implemented them in East Europe and Africa see Bernharrd, 2016.
} 
the supreme authority for the physical infrastructure of the state. This department, which cooperated with the Housing Ministry, dealt with the pressing mission of determining the geographic spreading of the population, an idea known as the "Population Dispersal Plan" (Sharon, 2006). This idea was the basis for the "Sharon Plan", published in late 1951, which was the first national master-plan, influenced to a large degree by contemporary European regionalist ideas (Sharon, 1952). As demonstrated by Smadar Sharon (2015), these ideas were not all German, as implied by much of the existing scholarship, but also came from other European backgrounds, e.g. Italian models.

Apart from the official institutions, a group of planners, economists and public functionalists who held a "regionalist" ideology had founded the "Settlement Reformation Circle". This group (which included Arie Dudai), had a considerable effect on the formulation of the populating and planning policies of the state. ${ }^{4}$ The group played an important role in initiating the population dispersal policy, as well as in delineating spatial planning vested in the regionalist paradigm, which lead to the founding of new towns and cities. It also influenced the development of landscape preservation initiatives, and introduced values of protection of wildlife and the natural habitat as well as historical heritage (Reichman and Yehudai, 1984). Architect Eliezer Brutzkus was the most prominent member of the forum, and he was responsible, to a large extent, for the development program of the newly established state, which was carried out in a distinctively regionalist spirit (Brutzkus, 1982).

The regional planning doctrine prioritized agricultural development as a source of employment. It drew upon ruralist and anarchist approaches (Feitelson, 2012), as

\footnotetext{
${ }^{4}$ Current researchers dispute this assumption and claim that the Society's effect on formulating the planning paradigm was limited, and primarily served Brutzkus to fortify his own position and advance his own convictions. See: Wilkof, 2018.
} 
well as on Zionist ideology, which saw agrarian and agricultural settlements as ideologically preferable to the bourgeois, "diasporic" city (Barkai, 1981). As a result, regional-agrarian development (Weitz, 1968) was prioritized in regional planning in Israel, including the founding of new regional urban centers (known as "Development Towns").

Two prevalent approaches coincided within the Planning Department itself, one represented by Arthur Glikson and the other by Eliezer Brutzkus. Brutzkus supported a functionalist-economic approach, which promoted urban development in optimal locations in terms of employment, economic development and transportation. This approach was rooted in Geddes' doctrine and based its decisions on quantitative data, economic programs and sociological principles (Hysler Rubin, 2011). Arthur Glikson, on the other hand, supported an "ecological" approach, which prioritized physicalgeographic criteria such as topography, climate and landscape planning, and was strongly affected by the principles developed by Lewis Mumford.

Glikson and Brutzkus thus promoted very different conceptions of regional planning, and struggled for their implementation in the planning practices of the postindependence period. They also contributed to the theoretical evolvement of these conceptions, publishing numerous texts in which their approaches were formed in light of their experience in Israel (Brutzkus , 1970; 1973; Glikson, 1953; 1958; 1967; 1971) and abroad (Glikson, 1970). ${ }^{5}$ For our purposes it is important to understand the production of local spatial knowledge, based on the Israeli experience of the early state, coupled by the European knowledge which the planners had acquired during their

${ }^{5}$ This publication, which refers to the work of Glikson, Weitz and others in Crete in the early 1960 's, based on the development of the regional planning paradigm, has been studied recently, see: Kallus, 2015. 
education in Europe between the Wars. This knowledge was later re-developed and circulate to Africa.

As we shall see in the following section, Arie Dudai, who was a central member of the founding generation of the discipline of planning in Israel, and Ursula Oelsner, who belonged to the "second-generation" (Efrat, 1997), had both assimilated these notions of regional planning. They implemented theoretical and practical ideas of regional planning in their work in Israel and in Africa, where their biographies intersect with the geographical flow of knowledge.

\section{Methodology}

On the basis of the geo-biographies of Dudai and Oelsner, this study creates a "thick description" (Geertz, 1973) and an analysis of two place-based planning cases (Macabit/Modi'in and Sierra Leone), and relates them to the planners' personal biographies. Since both planners have passed away years ago, we based our research on archival materials, planning documents and reports, and a series of in-depth interviews made during the summer of 2016 with planners, architects and family members that were familiar with the planners' personal and/or professional activities. The interviews shed light on unknown parts of their life and work. They were transcribed and analyzed thematically and helped us understand the role of their geobiographies in the production and circulations of spatial knowledge.

We chose two different case studies, from Israel and Africa. The cases were planned during the same period, but differ in scale (regional, national) and in their level of detail. These two cases, which are not easily comparable, nevertheless provide good examples of the ways in which the two planners produced their professional knowledge (mainly the concept of regional planning) based on their biegeo-biographies. It is important to note that these cases are neither typical examples of Israeli planning at the 
time, nor models for planning in Africa, but can shed light on the issue of spatial knowledge, its production and circulations.

\section{The Geo-Biographies of Arie Dudai and Ursula Oelsner}

Arie Dudai was born in 1911 in Ukraine, and immigrated to Palestine/Eretz Israel as a child. After graduating from high-school in Tel-Aviv, he studied architecture in Belgium and later moved to England. When World War II broke out, Dudai joined the British Air Force and was trained as a pilot. Upon his return to Israel after the war, he was drafted by the Israeli army and fought in the 1948 war, before embarking on his architectural career.

In 1949, he joined the Governmental Planning Department led by Arieh Sharon and Tzion Hashimshoni. Dudai became involved in the preparation of regional plans that were part of the "Sharon Plan" (Sharon, 1952), which was the first national master plan. As Brutzkus recalled, "...the Planning Department was a spot to where all those who had stature and experience in urban planning, some of whom were widely renowned, flocked" (Brutzkus, 1982).

Dudai was in charge of planning section in the Tel-Aviv region, assigned to the Ministry of Interior, in which he represented the Planning Department and its innovative agenda in the regional and local building committees. In this position he identified himself with new ideas, and promoted their realization vis-à-vis a variety of parties with persuasiveness and personal, informal commitment. These "diplomatic" talents were to serve Dudai well in his future roles. During these years Dudai travelled across the world to attend professional workshops and conferences, and met prominent planners and policymakers in England and in organizations such as the United Nations, among others. 
In 1953, Dudai left the Planning Department and was appointed as chief planner of the Settlement Department of the Jewish Agency. In his new role, he was intensively involved in the large-scale regional plans for the Ta'anach, Adolam and Lakhish areas, formulated during that time (Witz, 2003).During this period, the Department was at the height of its power and influence, controlling enormous budgets and directly responsible for the majority of construction work in the country. The Department's work wasn't restricted by any impeding statutory framework until the Israeli Planning and Construction Law was passed in 1965 , and it attempted to position itself as the leading factor in urban and regional planning. Dudai used his senior position to promote construction and housing, guided by his conviction that "it has been left to us, to carry out the honorable task of designing the physical background to the life of the Israeli citizen" (Dudai, 1961: 2).

Conflicts with the politicians within the Ministry of Interior and professional disagreements led to his resignation after several years in 1960. Around this period Dudai started teaching in the Technion, and in 1962 he began to attend meetings which were conducted inplanner Rachel Wilkanski's house in Tel-Aviv, out of which eventually grew the Environmental Planning Union. Dudai was subsequently appointed to be the union's second chairman in 1967 (Rachel Wilkanski, Interview, 26 July 2016).

With the expansion of Israel's ties to developing countries in Asia and Africa in the early 1960's (Yacobi, 2016), joint initiatives of the Ministry of Foreign Affairs and the Ministry of Housing have led to the founding of "The Institute for Planning and Development, LTD" (IPD). This public-private institution aimed to procure and process large-scale development projects in developing countries at the behest of their governments, and worked in Israel as well in the field of regional planning. Dudai was appointed to be the Institute's manager in the early 1960's, and, according to Brutzkus' testimony: 
This job was a perfect fit for him, as someone who had great orientation skills that enabled him to adjust to new and wildly different circumstances, a 'man of the world' ... he managed to forge ties and even personal friendships with several African leaders... He advised, investigated possibilities and continuously attempted to influence governments to commission projects of regional and urban planning, construction and housing from the Israeli Institute (Brutzkus, 1982, 6).

This is an important period in Dudai's biography, since the three planning documents that we analyzed as case studies were prepared as part of the Institute's work under Dudai's management.

The IPD was active until the mid-1970's, but had only limited success. The Institute depended on commercial profitability and paid project processing. However, developing countries received multi-dimensional and free of charge aid programs, including specialized services and project processing, from international bodies (The World Bank, the United Nations, etc.) as well as governments from both West and East. They therefore did not hasten to commission fully-priced projects from the Israeli Institute (Brutzkus, 1982). Deterioration of the Institute's stature and scope of activities followed the decline of Israeli international relations, which culminated after the October 1973 war in severing diplomatic ties and ending Israeli development export to Africa. In the early 1970's Dudai left the Institute and was appointed to be a UN representative in Singapore.

Dudai headed the UN Singapore-based planning team, which produced a master plan for the island and its 4 million inhabitants. Based on the knowledge and experience he had attained throughout his career, his approach to this plan is relevant to the casestudies we will discuss in Israel and Sierra Leone: 
I believe that a master-plan should be a concept plan - a hypothetical plan or a concept plan alone, the plan of development policy.... After four and a half years working in Singapore we presented the Singaporean government with a concept plan on which one can begin building, a plan that enables the development of detailed plans necessary for future planning (Dudai, 1975: 111).

Following the completion of the Singapore plan, Dudai returned to Israel and was commissioned by the Ministry of Housing to prepare a conceptual plan for the future development of Mitzpeh Ramon. He died in 1982 [while working on this final commission?].

Ursula Oelsner was born in 1934 in Breslau, Germany. In 1939 her family immigrated to England for the duration of the Second World War, and later moved to the US to reunite with family members living in New Orleans. There, Oelsner studied architecture and worked as an architect for a short period, before travelling to Singapore [when?], where she worked as a planner for the UN Despite a severe disability. She later moved to one of the Greek islands (apparently in Santorini), where she took part in a planning project. $^{6}$ Oelsner immigrated to Israel at the end of the 1950 s, intending to work as a planner, and therefore she contacted Tzion Hashimshoni who was working on a master plan for Tel-Aviv at the time. According to Wilkanski (Interview, 26 July 2016) Hashimshoni assured Oelsner that she would be employed within the project, but later failed to keep his promise.

Oelsner was accepted to the IPD under the management of Dudai. At the time, this was a cutting edge, dynamic planning body, as attested by Ruthi Friedmann, (Interview, 22 June 2016) an economist and close friend of Oelsner:

${ }^{6}$ It is conceivable that this is where she met Dudai, who allegedly was also involved with planning projects in the Greek Isles during the 1950's. 
They laid foundations here, based on their knowledge from abroad and their local experience, which were ground-breaking. The challenge of creating something new, almost ex nihilo, learning from what happened here in Israel but incorporating that with the understanding and knowledge they brought from abroad, made them do very original things that were in demand there, in Africa, as well.

According to Friedmann, working in the IPD matched Oelsner's wide horizons, background and international experience and her knowledge of foreign languages, since much of the work was commissioned by foreign governments and bodies.

In the early 1960's Oelsner, together with Dudai, Glikson, Harry Brand, Shmuel Yavin, Asher Stup, Yonah Ginzburg, Dalia Litvin, Meira Gluskinos, Ayala Hirsch and others, attended meetings of planners, architects, economists and sociologists in Rachel Wilkanski's Tel Aviv apartment - meetings which bred the Environmental Planning Association. The Association was a meeting place between youngsters and highranking persons in the field, and was founded on the belief that planning was not an exclusive practice to architects, but required: "cross-fertilization between architects and planners and experts in various disciplines such as economists, sociologists, geographers and more, who could meet and discuss planning in the broad sense of the term" (Harry Brand, Interview, 28 July 2016). This approach to planning was highly characteristic of Oelsner, who: "arrived to Israel with an extraordinary understanding of the different tenets of planning and a much broader knowledge than existed here in Israel in regards to the profession... Ursula ardently supported the inclusion of nonarchitects in planning, and the insertion of non-physical elements to planning, such as economic programs (Ruthi Friedmann, Interview, 22 June 2016). 
Oelsner was influenced by Brutzkus's work in regional planning and together with the economist Friedmann, began to work on developing the economic aspects of regional planning as a means to promote social justice.

During the 1960's Oelsner left Israel for a short period in order to complete her master's degree in England, but returned in 1967 following the war, and resettled in Tel-Aviv. In 1977 she gave birth to her only daughter, whom she raised as a single mother, and moved to Jerusalem. With the closure of the IPD she began to work in the Ministry of Housing, a position she held until her sudden death in 1998.

Oelsner was highly motivated and opinionated, determined and restrained, and did not allow the language barrier or her physical disabilities to stand in the way of her professional or personal life. She was outspoken about her socially-progressive opinions in every forum. Oelsner was an adventurer who took pleasure in travelling around the world. She had had many friends in Israel and worldwide, amongst them Palestinians, whom she encountered both in her professional work and in her political activism within radical left movements, particularly in Jerusalem during the 1980's and 1990's.

\section{From Israel to Africa and back}

In this section we will see how the concepts of regional planning had traveled and were embedded in the joint work of Dudai and Oelsner. To that end we will focus on three projects of regional planning in different scales - the first is "Macabit - a conceptual framework towards the planning of a new city" (Dudai and Oelsner, 1964), the second project is the "Sierra Leone national Urbanization Plan" (Dudai and Oelsner, 1965), and the third, "Modi'in -plan proposal for a new city" (Dudai, Oelsner, et al, 1968). These documents were published by the IPD under Dudai's management. We will analyze the 
three documents in order to understand the politics and movement of planning knowledge, particularly ideas grouped under the paradigm of "regional planning".

Macabit - A Conceptual Framework Towards the Planning of a New City (1964) and Modi'in-Plan Proposal for a New City (1968)

As the latter is, to a great degree, a continuation of the former, these two documents shall be discussed jointly. The first document was defined as a "conceptual framework towards the development of a new city", or what today may be called a "masterplan", i.e. a non-statutory plan that includes elements that could serve as a basis for future planning. In 1964, the year the document was published, the region intended for planning was a frontier region, close to the Jordanian border on one side and to Israel's major urban center on the other. The plan explicitly referred to the fact that Tel-Aviv and the surrounding urban strip is home to half of the country's population. This area underwent rapid changes in the preceding decades, especially after Israel's independence:

As a result of the congestion of the population, services, facilities, manpower, industries and communication and media outlets - this region is where the most intensive economic activity and most dynamic processes of development in the country take place... Tel-Aviv is congested and weighed down by the pressure of regional and national growth... Certain planning steps will be taken that will take the entire region into consideration and not only the city of Tel-Aviv as at self-standing [an independent?] unit (Dudai and Oelsner, 1964: 7).

The plan, commissioned from the Ministry for Planning and Development by the Ministry of Housing, was informed on one hand by a conceptualization that is based in part on the old paradigm, instituted by the Planning Department under Sharon and in 
the Settlement Reformation Circle, of creating a "functional" settlement hierarchy (Brutzkus, 1981). On the other hand, the quote above points to a conceptual shift, based on a new observation conducted within the premise that settlement hierarchies cannot be created only by developing settlements ("Development towns" and agricultural settlements) in the frontier regions, which are distant from the economic and cultural centers, as was attempted in the "Sharon Plan".

The current plan suggested taking into consideration the fact that the business, economic, touristic and cultural center will remain in metropolitan Tel-Aviv for years to come. The plan suggested, therefore, to establish a new city in the frontier area close to Tel-Aviv as well as to Jerusalem, the State's capital and home to the administrative and governmental apparatus. Development, Dudai and Oelsner argued, "Can offer a foundation for an orderly redistribution of industrial activity, reinvigorate population dispersal, encourage the development of a regional transportation system and locate additional municipal services. On the planning level it can support the beginning of a Greater Tel-Aviv area" (Dudai and Oelsner, 1964: 3).

Planning, in this case, does not only consider the new city and its immediate surroundings, but also adopts a regionalist perspective. For example, part of the discussion is dedicated to the "Tel-Aviv area and the new city", explaining that "The present decision to build the city of Macabit derives from a consideration of the TelAviv area as a unit, and an understanding of its role within the country..." (Dudai and Oelsner, 1964: 3).

Dudai and Oelsner stated that the new city was an initiative of an interministerial committee that commissioned them with the planning. However, they argued that the "Concerted efforts to divert some of the services and populace dependent on the city away from it, fit within the scope of a comprehensive policy of regional planning" (Dudai and Oelsner, 1964: 5). Planning was therefore the product of 
official spatial policies, but it was also based on regional planning principles, which included not only landscape and physical considerations, but also demographic, economic and social ones. Yet the old ideas devised in the 1950's, of a balanced urban hierarchy and median towns that constitute regional centers, still feature prominently in the planning of Macabit (Dudai and Oelsner, 1964: 10).

The social aspect is highly significant within the plan, which aimed to target a diverse population: "Macabit will draw a most diverse population - people with different and diverse talents, with widely varying specializations, employment, incomes, ages, origins, interests and characters" (Dudai and Oelsner, 1964: 3). In addition to the considerable portion dedicated within the plan's documents to these aspects, a six-page appendix entitled "Macabit and the Tel-Aviv Region: SocioEconomic Background" was added to the sections analyzing the area physically. The inclusion of this appendix is congruent with the innovative approaches and the emphasis on social and economic aspects that characterized Dudai and Oelsner during that period, and is equally evident from the interviews we conducted.

\section{[PLEASE PLACE FIGURES 1-2 ABOUT HERE]}

In June 1968, four years after the publication of "Macabit - a Conceptual Framework Towards the Planning of a New City”, another document was prepared for the Ministry of Housing by the IPD, entitled "Modi'in: Proposed Plan for a New City". This document is a proper masterplan and is much more comprehensive than the conceptual framework previously published for Macabit, but has a different name for the planned town. The plan includes a section dealing with surveys of Modi'in and the adjacent area; another section that comprises the city blueprints; and a third section dealing with infrastructure such as water and sewage. 
In terms of planning policy and spatial politics, this is a direct continuation of ideas previously outlined by Dudai and Oelsner. Dudai articulated this in the introduction:

The planning of Modi'in was initiated as a result of political as well as physical planning considerations, both on a national scale and on the scale of the Greater Tel-Aviv metropolitan area... Undoubtedly Tel-Aviv will remain the economic center of the country, and it is obvious that this area will continue to sustain the largest concentration of population... (Dudai and Oelsner, 1968: no page number indicated).

Dudai's introduction includes the regional principles employed in the planning of the city:

A final plan has yet to be developed, but in light of past developments, one can anticipate some principle tendencies. One is the necessity for a "satellite" town for Tel-Aviv. This town will complete the urban formation in the metropolitan area, being a link in the chain of sub-centers surrounding the municipal congestion of Gush Dan [the metropolitan area of Tel-Aviv]. The location of this urban settlement was set in the foothills of the Modi'in hill range, separating the mountainous regions and the coastal plains (Dudai and Oelsner, 1968: no page number indicated).

The plan includes blueprint drawings of neighborhoods in the town, as well as the commercial center and its access routes and various auxiliary systems. The written document of the plan includes an analysis of the social, economic, demographic and environmental sections, already presented in the Macabit conceptual framework. Dudai stated that this plan was based on the earlier project, and allowed for flexibility: 
The process is based on feedback, and the master plan of Modi'in will serve as a basis to be improved and amended in accordance with future developments in the science of planning and in the situation in our country and in the region. The plan will be constantly examined and tested in relation to a constantly-changing reality (Dudai and Oelsner, 1968: no page number indicated).

Dudai describes the objectives determined for the planning process, including "the preparation of a base for planning subject to future implementation, when the need for establishing a city will arise" on the one hand, and "the preparation of a framework and plan for immediate implementation, if need be", on the other (Dudai and Oelsner, 1968: no page number indicated). These principles of conceptual and operational flexibility are congruent with Dudai's later statements presented above, regarding the requirement for conceptual frameworks and flexible modes of operation that permit additions or subtractions and implementation subject to demands. The flexibility to incorporate future developments is evident in most parts of the plan. Thus, for example, the section dealing with "the position of Modi'in within the evolving regional system", contains the statement that: "The examination of possibilities for solving the transportation problems in the metropolis has not yet been completed, and it is expected that further development of possible solutions will yield more results, in addition to the current ones" (Dudai, 1966: 4).

In fact, this plan was never authorized, nor implemented. Ironically, despite the intensive and thorough work conducted by the IPD and expressed in the two plans, Dudai and Oelsner's contribution to planning the city of Modi'in was almost entirely erased from history. In the introduction to the plan which served as the basis for the eventual construction of the city in the 1990's, (Ministry of Construction and Housing, 1990) it is stated that: 
The planning of Modi'in is the result of a planning concept that was developed for many years, receiving governmental approval with the decision (Decision Number 1196 from 22 December 1985) to found an urban settlement which will be planned in the Modi'in area by the Ministry of Construction and Housing (ibid, 7)

The references in the document do not mention the work conducted by Dudai and Oelsner. An article discussing the history of the planning and development of the city of Modi'in (Golani, 1997) mentions that the initial ideas were drafted in the 1950's, but gives no credit to Dudai and Oelsner. On top of the fact that no use was made of Dudai and Oelsner's work in the plan eventually realized during the 1990 's, it is interesting to note that architect Moshe Sfadia, who was responsible for the final plan, did not even acknowledge their contribution (Myron, 2014; Safdia and Cohen, 2014).

It is possible that Oelsner was sidelined by the higher-ranking officials in the Ministry of Construction and Housing, since in later years she opposed the establishment of the city, which she saw as detrimental to the development of the existing nearby Palestinian cities of Lod and Ramla. Her relatively radical political persuasions stood in stark contradiction to the overridingly institutional approach of the Ministry (Ruthi Friedmann, 2016?).

[PLEASE PLACE FIGURES 3-4 ABOUT HERE]

\section{The National Plan for the Urbanization of Sierra Leone}

In December 1965, the IPD published the "Sierra Leone National Urbanization Plan". This document was a comprehensive survey in preparation for an entire regional planning scheme for the country. The principles of regional planning were applied to 
the state, as a planning unit. As we have shown earlier, this was a common and accepted practice during the early 1960's, especially for developing nations.

Sierra Leone was a post-colonial state, small both in area and in population. A former British colony, it had inherited British colonial practices and traditions, expressed for example in its institutes for higher learning that were built during the colonial era. The plan included sections dealing with the various issues - socioeconomic (industry, transportation, demographics, population etc.), and physical (climate, physical structure, regional characteristics etc.) and despite the highly different context, it resembles in its style of analysis, suggested categories and graphic layout the plans for Macabit and Modi'in.

The concept for the plan was conceived in 1960, when Dudai was asked by the Department for International Cooperation in the Israeli Ministry of Foreign Affairs to advise the Sierra Leonean government regarding urban development problems in its capital Freetown (Dudai, 1966). That same year, Foreign Miniter Golda Meir visited the country as part of her tour through the region. Sierra Leone was one of Israel's closest allies in the continent. Israeli aid to the country included, during the first half of the 1960 's, security aid and direct involvement in the founding of a military academy for infantry officers in 1967, with seven Israeli military experts acting as advisors (Oded, 2011).

The outline of the project was presented by Dudai at the Center for Settlement research [at the Israeli National University Institute for Agriculture], and a summary was published in Hebrew in a professional journal (Dudai and Oelsner, 1967). The plan was halted and therefore never brought to fruition, and did not attract scholarly attention until lately. ${ }^{7}$ As mentioned above, Dudai left the IPD in the early 1970's to work for the

${ }^{7}$ The study of Ayala Levin (2015) is the first and most comprehensive to date, dealing with Israeli architecture and planning in Sierra Leone in general, with a chapter dedicated 
UN in Singapore. The diplomatic relations between Israel and most sub-Saharan African countries including Sierra Leone were severed after the October 1973 war between Israel and Jordan, Syria and Egypt (Oded, 2011).

Planning and development export was part of Israeli foreign aid to Africa, from the early 1950's until $1973,{ }^{8}$ especially in Sierra Leone, where the presence of "Solel Boneh" was highly visible and many architectural initiatives were carried out. According to individuals involved (Weitz, 2003), aid in these fields began randomly, motivated by an ambition to export Israeli knowledge in the field of planning and development, particularly following the Lakhish region planning project (Sharon, 2016). Others claim that this project "points to the turning of Africa into a laboratory where spatial-colonial practices, dealing with population management and spatial designing, were tested" (Yacobi, 2016: 17). Further claims state that the expertise of Israeli architects in Africa during this period was a means to imagine African geography, and to consolidate moral justifications for interference in its territory. Despite the professional experience that coexisted with moral and political considerations, some argue that Israeli knowledge was imposed on the Africans, while the premature departure of the Israeli experts and planners left some large-scale broken promises in its wake.

Dudai spent two months in Sierra Leone in order to study the urban problems, and in light of his planning approach, had arrived at the conclusion that:

specifically to this plan. However, she does not recognize Ursula Oelsner's role and her contribution to the plan, only mentioning Oelsner in the bibliography. The chapter deals only with Dudai's work. He was, admittedly, the lead in creating ties with high-ranking Sierra Leonean government officials, but the work was conducted and signed by both Oelsner and Dudai.

${ }^{8}$ Planning and development aid during this period was not exclusive to Africa and was extended to Asian countries as well. See: Feniger and Kallus, 2016. 
Although it is possible to advise about planning the city itself and [it is equally possible to] prepare an urban plan, no good will come of it. The true problem lies in the lack of a plan to develop the country, the absence of policy to direct the development, and the resulting concentration of all activities in the capital and its constant, troubling growth that is disproportionate to the development of the rest of the country (Dudai, 1966, 20).

In a tour through the countryside Dudai was convinced of the necessity to prepare a comprehensive regional and national plan for the development and urbanization of the entire country. Following a report that he had submitted, and much correspondence regarding the subject, the Sierra Leonean Minister of Housing and National Planning visited Israel. In 1964 a budget for the conduction of a preliminary survey was approved, with the intention to briefly outline central trends and assist in securing further funding for the remainder of the project.

The plan was based on data collected by the Sierra Leone government, its various Ministries, official institutions, factories and universities, as well as international surveys conducted in the country. This data was used to draft a "comprehensive, overarching survey for the analysis of the findings and for determining principle guidelines for the [state's] urbanization program" (Dudai, 1966: 20). The published survey was put to State use and was presented as an initial, preliminary plan for the country (Levin, 2015).

As in the cases of the plans of Macabit and Modi'in, it has been argued that this plan was based on the principles of zoning, regional planning and pro-active modernist planning (Levin, 2015). As Dudai explained (Dudai, 1966), these principles included primarily ideas developed in Israel, such as population dispersal, the creation of a balanced urban hierarchy, and the establishment of middle-towns that will serve the 
agricultural-agrarian hinterlands. As discussed above, these regionalist planning principles were rooted in methodologies originating from Europe and the United States and were applied in Israel in the 1950's (Sharon, 2016).

Like the Sharon plan, in which Dudai had participated, the Sierra Leone Urbanization Plan was a national plan. However, as Levin points out (Levin, 2015), it was not entirely different from the Israeli regional plans of Lakhish, Adolam and Ta'anach, since it consisted of zones, but did not stipulate the construction of new cities from scratch. Rather, the expansion of pre-existing local villages was preferred, perhaps as part of the lessons learned from the shortcomings of regional planning in Israel. Dudai described it thus:

We developed an idea of creating urban centers of sufficient importance to become a counterbalance in the process of developing the country. This will also preserve the social potential, as cultural and economic regional development will not fall behind that of the capital to the extent that it currently does (Dudai and Oelsner, 1968: 24).

The planning philosophy that guided Dudai and Oelsner, evident in the plans of Macabit and Modi'in as well, upheld multi-dimensional planning, comprehensive on one hand but flexible on the other, outlining general instructions but not statutory, with a strong emphasis on socio-cultural and economic issues. This, for example, is how the planners present the project (our emphasis):

Planning should be multi-dimensional, consisting of different branches that comprise an overall plan. It should cooperate with national factors and localregional factors at the same time... Much importance should be accorded to the cultural aspect... Such planning should be comprehensive, broad, flexible and directed to select spots... [This is ] an approach that enables the construction of 
a broad, flexible framework, one that will serve as a point of departure and orientation to develop each part of the plan, and provide an outline for development, based on a framework of urbanization (Dudai and Oelsner, 1965: 32).

As in the plans of Macabit and Modi'in, the planners were aware of the proposed plans' shortcomings, and alluded to their proposals reflexively:

The primary accomplishment of our work is the fact that with little means, in a relatively short time and using pre-existing data, we have managed to prepare an initial plan for the urbanization of the country. It is clear to us that our work is incomplete and that an examination of our conclusions, a deepening of our thoughts and, in general, clearer and more accurate planning proposals are in order... It seems to us that this is the way to plan comprehensive regional plans in the developing countries... (Dudai and Oelsner, 1965: 32).

\section{[PLEASE PLACE FIGURES 5-6 ABOUT HERE]}

\section{Conclusions}

In this article we discussed the production and circulation of spatial knowledge by highlighting the role of the geo-biographies of planners. Our aim was to present the geographies of regional planning knowledge, which materialized in the West during the first half of the twentieth century, within the frame of the regional planning paradigm in its journey from Europe to Israel and African. This was done by tracing the work of Dudai and Oelsner in both these places during the 1960's. By revealing the geobiographies of these two planners, we uncovered their contribution to the Israeli planning history, which was, to a large extent, missing from the research of planning and geography. We believe that the geo-biographies of spatial knowledge contribute to 
an understanding by geographers and planners of the production and circulation of spatial knowledge, both theoretically and empirically.

As we have demonstrated, planning knowledge has both a geography and a biography. While the "global" context of regional planning emanated from the discourse and practice of planning in the global level, the Israeli-regional context has been relevant as well. Israel was a "spatial and architectural laboratory" (Yacobi, 2015) where various forms of settlement were conceived in the spirit of regional planning. The biographical context derives from the considerable experience and international backgrounds of Dudai and Oelsner, which formed a solid foundation to understanding the challenges they faced in Sierra Leone. The biographical dimension, expressed in the life stories of the two planners, is what used to chronicle geography (and planning) as a discipline, a discipline with history that relies on biographies (Moss, 2001). Historical perspective, claim Shevah and Kallus (2016), affords planners with a better understanding of current contexts and situations. Thus, understanding and learning the geo-biographies and history of planning projects, paradigms and planners, could lead to better planning today.

Regional planning as theory and global practice was brought to Israel, where it was reformulated. It was then transferred to the newly independent African states, where it played a role in the consolidation of national territories in Africa, as part of the Israeli policy during these years (xxx, 2015).

Researchers of geographies of planning knowledge in the twentieth century have pointed out that the movement of knowledge in planning and development flows in a visible direction - from Western countries, primarily in Western Europe and North America, to developing countries. This movement has different analytic models that are related to different political constellations and the characters of the national entities in which the traffic of knowledge takes place, as well as to the human agents involved 
(Ward, 2002). On the other hand, the place itself and the transformations in the knowledge have consequences to the case in point, since regional planning, although rooted in Western theoretic principles, was developed and transformed as a result of attempts to apply it in Israel, prior to its continuation to Africa and other places.

The case studies presented here not only unveil the biographies of "forgotten" planners and reintroduce them to the historical discussion about Israeli planning, but also encourage contingent reflections on the flow of knowledge and planning development as a non-unilateral nor temporally constant phenomenon. Dudai and Oelsner's work, which adopted and reinterpreted the paradigm of regional planning, was carried out in Africa and Israel simultaneously, and did not necessarily abide by the formula of adopting knowledge, configuring it to a new arena and, later, exporting it elsewhere. In these cases the planners used knowledge that arrived via Israeli planners who studied abroad before 1948 (Ward, 2002), and was further developed during the 1950 's. In this paper, we focused on these "human agents" and their geo-biographies, claiming that these biographies have their own importance for the flow of knowledge.

Unlike planners and architects who were based in Israel and later moved to work abroad and exported their experience to Africa (Yacobi, 2016), Dudai and Oelsner worked simultaneously during the 1960's on the development of their ideas about the application of regional planning to Israel - in Macabit and Modi'in, and in Sierra Leone. The difference between the scopes of these projects is enormous, but the basic premise is similar - flexible planning, non-statutory, based on comprehensive survey work and economic programs and with a strong emphasis on social issues. These pioneering ideas were not realized in any of the cases, but their importance derives from their theoretical and professional innovation, as well as their deep seated, relatively progressive outlook for their time. Dudai and Oelsner have contributed to the development of ideas of regional planning as well as to the outreach of professional knowledge, thanks to their 
broad horizons and international experience, and are worthy of documentation and research.

\section{Bibliography}

Barkai, Z (1981). Regional Planning - The village and the Town, Karka Journal of the Land-Use Research Institute, 23: 14-18. (Hebrew).

Beauregard, R (2016). The Neglected Places of Practice, in: Susan S. Fainstein and James Defilippis (eds), Readings in Planning Theory, Chichester: Wiley Blackwell, 277-292.

Bernhard, P (2016). Hitler's Africa on the East: Italian Colonialism as a Model for German Planning in Eastern Europe, Journal of Contemporary History, 51(1): 61-90.

Brutzkus, E (1970). Regional policy in Israel. Jerusalem: Ministry of Interior, Town and Country Planning Department.

Brutzkus, E (1973). "Concentration and dispersal trends in Urban Planning", In: Dan Suan (ed.), Regional Planning: What about and Why - Symposium. Tel Aviv: The Institute for the Research of Construction and Industry and the Association of Engineers and Architects in Israel: 7-19. (Hebrew)

Brutzkus, E (1981). "The 'Dreams' that became Cities", In: Naor, Mordechai (ed.), Olim and Transition Camps 1948-1952: Resources, Summaries, Select Episodes and Supplementary materials, Jerusalem: Ben Zvi Institute: 127-140. (Hebrew) 
Brutzkus, E (1982). In Memory of Arieh (Liyulah) Dudai. Environmental Planning - The Environmental Planning Society Quarterly, 28: 4-6. (Hebrew).

Campbell, H (2012). Planning to Change the World: Between Knowledge and Action Lies Synthesis, Journal of Planning education and Research, 32(2):135146.

Daniels, S and Nash, C (2004). Lifepaths: Geography and Biography, Journal of Historical Geography, 30: 449-458.

Dudai, A (1961). Promotion of planning and construction in our country, Engineering and Architecture - Periodical of the Engineers and Architects Society in Israel, 5-6: 2. (Hebrew)

Dudai, A (1966). "Statewide Plan for the Urbanization of Sierra Leone - Survey in Preparation for Planning", In: Settlement and Development: Regional development projects. Rehovot: The Center for Settlement Research, National University Institute for Agriculture: 20-25. (Hebrew)

Dudai, A (1975). In preparation for efficient planning in Israel (Lectures and Discussions). Netanya: Ministry of Interior, Local governance division. (Hebrew)

Dudai, A and Oelsner, U (1964). Macabit - a Conceptual Framework Towards the Planning of a New City. Tel-Aviv: The Ministry of Housing and the Institute for Planning and Development LTD (IPD). (Hebrew)

Dudai, A and Oelsner, U (1965). Sierra Leone national urbanization plan. Tel-Aviv: Institute for Planning and Development LTD (IPD). 
Dudai, A and Oelsner, U (1967). National Urbanization Plan - Sierra Leone, Engineering and Architecture - the Engineers and Architects Society in Israel Periodical, 28(5): 4-31. (Hebrew)

Dudai, A, Oelsner, U et al (1968). Modi'in: Plan Proposed Plan for a New City. Tel Aviv: The Ministry of Housing and the Bureau for Planning and Development Ltd. (Hebrew)

Efrat, E (1997). Fathers and Sons in Physical Planning in Israel. Karka Journal of the Land-Use Research Institute, 43: 59-65. (Hebrew)

Feitleson, A (2012). "Physical planning to Israel: Between State, Society, Capital and Environment", in: Hasson, S (ed.), Shaping the space in Israel: The map of settlements and land. Tel-Aviv, Keter and JNF: 87-108. (Hebrew)

Feniger, $\mathrm{N}$ and Kallus, R (2016). Expertise in the Name of Diplomacy: The Israeli Plan for Rebuilding the Qazvin Region, Iran, International Journal of Islamic Architecture, 5(1): 103-134.

Fenster, T and Kulka, T (2016). Whose Knowledge, Whose Power? Ethics in Urban Regeneration Projects with Communities, Geografiska Annaler: Series B, Human Geography 98 (3): 221-238.

Forester, J, Fischler, R and Shmueli, D (2001) (eds). Israeli Planners and Designers, New-York: State University of New-York Press.

Fridman, J (1964). "Regional planning as a field of study", in: Fridman, J and Alonso, W (eds.), Regional Development and Planning. Cambridge, Massachusetts, MIT Press: 59-72. 
Friedmann, J (2010a). Crossing borders? Do planning ideas travel?. In: Healy, $\mathrm{P}$ and Upton, R (eds), Crossing borders: International exchange and planning practice. London and New-York, Routledge: 313-328.

Friedmann, J (2010b). Place and Place-Making in Cities: A Global Perspective, planning Theory \& Practice, 11(2): 149-165).

Geertz, C. (1973). The Interpretation of Cultures. Basic Books.

Glikson, A (1953). Regional Restoration: Lectures on planning and regional development within the Engineer and Architect continuing education program. Haifa: the Engineer and Architect continuing education program's publication. (Hebrew)

Glikson, A (1958). Two case studies: Rural planning and development in Israel, Housing, building and Planning, 12-13: 199-205. (Hebrew)

Glikson, A (1967). Man - Region - World. Tel-Aviv: Ministry of Housing. (Hebrew)

Glikson, A (1970). Planning regional settlement projects, comparative study: Background, experience, new trends. Rehovot: Settlement Study Center. The Center for Settlement Research, National University Institute for Agriculture (Hebrew)

Glikson, A (1971). The ecological basis of Planning. The Hague: Martinus Nijhoff. 
Golan, A (1997). The Theory of Central places and Israeli Geography: Space,

Holocaust, Modernism and Silence, Horizons in Geography, 46-47: 39-52. (Hebrew)

Golani, Y (1997). The planning and development of the City of Modi'in. Karka - Journal of the Land-Use Research Institute, 43: 52-64. (Hebrew)

Graham, S and Healey, P (1999). Relational Concepts of Space and Place: Issues for Planning Theory and Practice. European Planning Studies, 7(5): 623-646.

Healey, P (2004). The Treatment of Space and Place in the New Strategic Spatial Planning in Europe, International Journal of Urban and Regional Research, 28(1): 45-67.

Healey, P (2010). "Introduction: The transnational flow of knowledge and expertise in the planning field", in: Healey, $\mathrm{P}$ and Upton, R (eds.), Crossing borders: International exchange and planning practice. London and NewYork, Routledge: 1-26.

Hecht G. (2011). Entangled geographies: empire and technopolitics in the global cold war, MIT Press.

Hysler Rubin, N (2011). Patrick Geddes and Town Planning: A Critical View. London and New-York: Routledge. 
Jazeel, T (2016). Between area and discipline: Progress, knowledge production and the geographies of Geography, Progress in Human Geography, 40(5): 649-667.

Kallus, R (2015). The Crete development plan: A post-second world war Israeli experience of transnational professional exchange, Planning Perspectives, 30(3): $339-365$.

Leavitt, J (1980). The history, status and concern of women planners, Journal of Women in Culture and Society, 5(3): 226-230.

Lee, R (2013). Erica Mann and an intimate source: Some notes on Kenny Mann's 2014 documentary Beautiful Tree, Severed Roots, ABE Journal, 4: 111.

Levin, A (2015). Exporting Zionism: Architectural Modernism in IsraeliAfrican Technical Cooperation, 1958-1973, Unpublished PhD. Manuscript, New-York: Columbia University.

Longhurst, R (2009). Embodied Knowing, International Encyclopedia of Human Geography (pp 429-433). Eds.: Kitchen, R., and Thrift, N. Oxford: Elsevier.

McEwan, Cheryl. (2009). Postcolonialism and development. London ; New York : Routledge.

McGeachan, C, Forsyth, I and Hasty, W (2012). Certain Subjects? Knowledge with Biography and Life-Writing in Historical geography, Historical Geography, 40:169-185. 
Ministry of Housing, Department of Town Planning (1990). City in Modi in, Jerusalem: Governmental Print.

Moss, P (ed.) (2001). Placing Autobiographies in Geography, new-York: Syracuse University Press.

Myron, A (ed.) (2014). Modi'in the City, Jerusalem: Ben Zvi Institute. (Hebrew) Oded, A (2011). Africa and Israel: Uniqueness and Vicissitudes in Israeli Foreign Policy, Jerusalem: Mangess Press. (Hebrew)

Olufemi, O (2008). Experiential and emotional encounters of women planners in Africa, Development in Practice, 18(3): 412-419.

Perera, N (2008). The planners' city: the construction of a town planning perception of Colombo, Environment and Planning A, 40: 57-73.

Reichman, S and Yehudai, M (1984). Episodes in Physical Planning in Israel: an initiative Physical planning survey, 1948-1965, part 1, Jerusalem, Ministry of Interior, the Housing Administration and the Geography department, Hebrew University of Jerusalem. (Hebrew)

Roy, A (2010). "Poverty Truths: The politics of knowledge in the new global order of development", in: Healey, P and Upton, R (eds.), Crossing borders: International exchange and planning practice. London and New-York, Routledge: 27-46.

Safdia, M and Cohen, M (2014). "Modi'in: the Planning of a City", in: Myron, A (ed.) (2014). Modi'in the City. Jerusalem: Ben-Zvi Institute: 138-192. (Hebrew) 
Sandercock, L and Forsyth, A (1992). A gender agenda: New directions for planning theory, JAPA - Journal of the American Planning Association, 58(1): 49-59.

Schmidt, M and Purwins, S (2017). Simultaneity as a Challenge for Development, GeoJournal, DOI 10.1007/s10708-017-9828-1.

Shevah, D and Kallus, R (2016). Past Forward: Planning in the Light of Historical Knowledge, Journal of Planning History, 15(1): 29-45.

Sharon, A (1952). Physical Planning in Israel, Jerusalem, Government Publishing House. (Hebrew)

Sharon, S (2006). The Planners, The State and the formation of National Space in the early 1950's, Theory and Criticism, 29: 31-57. (Hebrew)

Sharon, S (2015). "Importation and translation of the Italian Colonial settlement model to the Lakhish region", in: Shenhav, Y (ed.) Zionism and Empires. Tel-Aviv and Jerusalem, Hakibbutz Hameuchad and Van Leer Institute Press, 301-326. (Hebrew)

Sharon, S (2016). The dialectic between modernization and orientalization: ethnicity and work relations in the 1950s Lakhish region project, Ethnic and Racial Studies, 40(4): 732-750.

Soja, E.W (2000). Postmetropolis: Critical studies of cities and regions, Oxford: Blackwell Publishers. 
Soja, E.W (2009). "Regional planning and development theories", in: Kitchen,

R. and Thrift, N (eds.), International Encyclopedia of Human Geography.

Oxford, Elsevier: 259-270.

Ward, V.S (2002). Planning the twentieth-century city, Sussex: John Wiley \& Sons, LTD.

Watson, W. (2009). Seeing from the South: Refocusing urban planning on the globe's central urban issues. Urban Studies, 46(11), 2259-2275.

Watson, W. (2012). Planning and the 'stubborn realities' of global south-east cities: Some emerging ideas. Planning Theory, 12(1), 81-100.

Weitz, R (1968). Introduction to regional-rural planning. Rehovot: The Center for Settlement Research, National University Institute for Agriculture. (Hebrew)

Weitz, R (2003). The Great Plough and the Planning Map: An overview of the history of planning in Israel, Jerusalem: Bialik Institute. (Hebrew)

Wilkof, S (2018). Defining the National Region: German-Émigré Planners and the Rise of Zionist-Israeli Planning 1933-1953, Unpublished PhD. Manuscript, Planning Department, University of California, Berkeley. Yacobi, H. (2009). The Jewish-Arab city: Spatio-politics in a mixed community. London: Routledge.

Yacobi, H. (2016). Israel and Africa: A Genealogy of Moral Geography. London and new-York: Routledge. 
Yiftachel, O. (2006). Re-engaging planning theory? Toward 'South -Easthern' perspective. Planning Theory, 5(3), 211-222. 